\title{
Effects of the basic fibroblast growth factor and its anti-factor in the healing and collagen maturation of infected skin wound ${ }^{1}$
}

\author{
Efeitos do fator de crescimento de fibroblastos básico e do seu anti-fator na \\ cicatrização e maturação do colágeno de feridas infectadas de pele
}

\author{
Antonio Medeiros Dantas Filho², José Lamartine de Andrade Aguiar ${ }^{3}$, Luís Reginaldo de Menezes Rocha4, Ítalo Medeiros \\ Azevedo $^{5}$, Esdras Ramalho ${ }^{6}$, Aldo Cunha Medeiros ${ }^{7}$ \\ 1. Research performed at Unit of Experimental Surgery, Department of Surgery, Federal University of Rio Grande do Norte (UFRN), Pos- \\ Graduation Program in Surgery, Federal University of Pernambuco (UFPE), Brazil. \\ 2. Master, PhD, Associate Professor, Department of Surgery, UFRN, Brazil. \\ 3. Associate Professor, Department of Surgery, UFPE, Brazil. \\ 4. Associate Professor, Department of Pharmacology, UFRN, Brazil. \\ 5. Graduate Student, Statistics, UFRN, Brazil. \\ 6. Graduate Student, School of Medicine, UFRN, Brazil. \\ 7. PhD, Full Professor, Department of Surgery, UFRN, Brazil.
}

\begin{abstract}
Purpose: The infection is one of the main factors that affect the physiological evolution of the surgical wounds. The aim of this work is to evaluate the effects of fibroblast growth factor (FGFâ) and anti-FGFâ in the healing, synthesis and maturation of collagen when topically used on infected skin wounds of rats. Methods: An experimental study was perfomed in 60 male Wistar rats. All animals were divided in two groups (A and B). Each group was divided in three subgroups A1, B1; A2, B2 and A3, B3. After anesthesia with pentobarbital, two open squared wounds $\left(1 \mathrm{~cm}^{2}\right)$, $4 \mathrm{~cm}$ distant to each other, were done in the dorsal skin of all the rats. In group $A(n=30)$ the wounds were contaminated with multibacterial standard solution, and in group $B(n=30)$ the wounds were maintained sterile. These wounds were named F1 (for inflammation analysis) and F2 (for collagen study). The open wounds of A1 and B1 rats were topically treated with saline solution, A2 and B2 were treated with FGFâ and subgroups A3 and B3 were treated with FGFâ and anti-FGFâ. The rats were observed until complete epitelization of F2 wounds for determination of healing time and the expression of types I and III collagen, using Picro Sirius Red staining. Inflammatory reaction in F1 wounds was studied using hematoxilin-eosin staining. The three variable was measured by the Image Pro-Plus Média Cybernetics software. The statistical analysis was performed by ANOVA and Tukey test, considering $\mathrm{p}<0.05$ as significant. Results: It was observed that infection retarded significantly $(\mathrm{p}<0.05)$ the time of wound scarring and the topical application of FCFb reverted the inhibition of healing caused by bacteria. The inflammatory reaction was greater in the subgroup B2 than in B1 and A3, and the difference was significant $(\mathrm{p}<0.05)$. It was observed greater expression of type I collagen in all the subgroups treated with FCFb, when compared with the untreated subgroups. Type III collagen was significantly decreased in wounds of B3 rats, comparing to the other subgroups. Conclusions: The $\mathrm{FCFb}$ accelerated the healing of open infected wounds and contributed with maturation of collagen, enhancing the type I collagen density. The anti-FCFb antibody was able to attenuate the production of both type I and III collagen. Key words: Fibroblast growth factors. Wound healing. Skin. Infection.
\end{abstract}

\section{RESUMO}

Objetivo: Avaliar os efeitos do fator de crescimento de fibroblastos básico (FCFâ) e do anti-FCFâ na cicatrização e maturação do colágeno em feridas infectadas na pele de ratos. Métodos: Um estudo experimental foi realizado em 60 ratos Wistar, divididos em dois grupos (A e B). Cada grupo foi divididos em 03 subgrupos A1,B1; A2,B2 e A3,B3. Após anestesia com pentobarbital sódico intraperitoneal, foram feitas duas feridas abertas de $1 \mathrm{~cm}^{2}$ na pele no dorso distando $4 \mathrm{~cm}$ uma da outra. Essas feridas foram denominadas feridas F1 (para análise inflamatória) e F2 (para estudo do colágeno). No grupo $A(n=30)$, as feridas foram contaminadas com solução multibateriana e no grupo $B(n=30)$ as feridas não foram contaminadas. As feridas receberam tratamento tópico com aplicação única. Nos subgrupos A1 e B1 foram tratadas com solução salina tópica, as dos subgrupos A2 e B2 foram tratadas com o FCFâ e nos subgrupos A3 e B3 foram tratadas com FCFâ e com o anti-FCFâ. Os dados formam analisados pelos testes ANOVA de Tukey, considerando $p<0,05$ como significante. Resultados: A infecção retardou de modo significante o tempo de cicatrização e a aplicação do FCFâ foi capaz de reverter a inibição da 
cicatrização provocada pela infecção( $\mathrm{p}<0.05)$. A resposta inflamatória foi maior nos grupos tratados com o FCFâ, e a aplicação do anti-FCFâ inibiu a reação inflamatória( $\mathrm{p}<0.05)$. Houve aumento significante dos colágenos tipo I e III em todos os subgrupos tratados com FCFâ, comparando com os não tratados, sendo a expressão do tipo I mais intensa do que do tipo III $(\mathrm{p}<0.05)$. A aplicação do anti-FCFâ inibiu a expressão das moléculas do colágeno. Conclusões: O FCFâ foi capaz de acelerar a cicatrização de feridas abertas infectadas e contribui para a maturação do colágeno, ao aumentar a expressão do colágeno tipo I, fenômeno que foi atenuado pela ação do anti-FCFâ.

Descritores: Fatores de crescimento de fibroblasto. Fibroblastos. Cicatrização de feridas. Pele. Infecção.

\section{Introduction}

The open surgical wounds heal mainly for two basic mechanisms: contraction of the borders of the wounds and migration of epithelial cells. The contraction reduces the size of the total thickness of the operative wound through centripetal movements of the skin surrounding tissues. Afterwards the capillaries of the wound margins form new vassels, migration of fibroblasts happens and the wound will be fill out ${ }^{1,2,3}$. The contraction of the open wounds depends on the capacity of the fibroblastos to contract and move through the extracelular matrix. The wounds contraction is influenced by many factors, such as: steroids use, diabetes, avitaminosis and infection. The infection is one of the main factors that alter the physiologic evolution of the wound healing ${ }^{4,5,6}$. The bacteria can affect the contraction of the wounds by many mechanisms. Perry and Sutkin et al demonstrated that the bacteria secrete exogen plasminogen activators, and produce proteolitic enzymes that may affect the extracelular matrix, blocking the wound contraction ${ }^{8}$. The bacteria are capable to inhibit the angiogenesis, reducing the two mechanisms of wound contraction ${ }^{9}$. It has been demonstrated that the basic fibroblast growth factor (FGFß) it is capable to revert the effects of the infection on the contraction in open wounds in all of the phases of the healing, through the fibroblasts formation and migration. In spite of reducing the time of healing, some studies demonstrated reduction in wounds strenght. FGFß has been able to improve the healing of incisional and open infected wounds by reducing its healing time, and increasing the DNA synthesis in extracellular matrix, without increasing the tensil strenght ${ }^{7,10}$. Broadley et al demonstrated that the neutralization of FGFß for a specific anti-body is capable to revert their functions, causing a significant reduction of DNA, proteins and collagen synthesis, affecting the cytokines function ${ }^{11}$. In experiments with topical application of FGFß a significant inhibition of the open wounds contraction was observed $^{12,13}$. Medeiros et al, as well as McGee et al, observed that topical application of FGFß in incisional wounds increased significantly the density of collagen and the tensil strength in rats o submitted to infection, steroids use, radiotherapy and imunossupressors ${ }^{14,15}$. Several studies have demonstrated that FGFß acts in the extracellular matrix stimulating angiogenesis, fibroblast migration, angiogenesis and fibrogenesis, enhancing the tensil strength and reducing the time for infected wounds scaring $3,4,5,6,7,8,9,10$. So, the purpose of the present work was to study the topical effect of FGFß and its anti-factor on infected skin wounds of rats. We evaluated the expression of types I and III collagen, as well as its maturation, the time for wound scaring and the inflammatory reaction in the involved tissues.

\section{Methods}

Sixty Wistar rats weighing $270 \pm 23$ g were used. Animals were provided by the Nucleus of Experimental Surgery of the Federal University of Rio Grande do Norte, Brazil, with the approval of Ethics Committee in Research (Animal Care). The International guidelines for the care and use of laboratory animals were followed throughout the study. The animais were acclimatized to the research laboratory for 7 days before we started the experiments. Rats were housed under controlled illumination (12/12 hours light/dark cycle), humidity (60-70\%), and temperature $\left(22^{\circ} \mathrm{C}\right)$. The animals were randomly separated in groups and subgroups (Figure 1) and observed in individual cages receiving water and food (LabinaPurina $\left.{ }^{\circledR}\right)$ ad libitum.

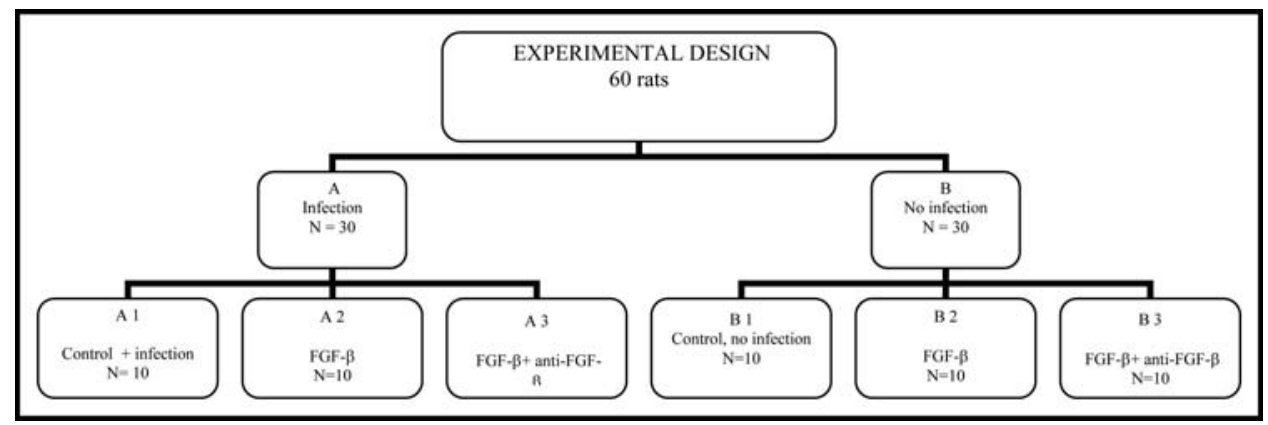

FIGURE 1 - Experimental design with distribution of 60 rats by groups and subgroups, and their treatments. 
After 12 hours of fasting, the rats were anesthetized by intramuscular injection of $30 \mathrm{mg} / \mathrm{Kg}$ of ketamine and $0,5 \mathrm{mg} / \mathrm{Kg}$ of xylazine. Afterwards, dorsal skin depilation and anti-sepsis with $1 \%$ povidone were performed. The surgical procedures were performed under aseptic conditions. Two open squared wounds $\left(1 \mathrm{~cm}^{2}\right), 4 \mathrm{~cm}$ distant to each other, were done in the dorsal skin of all the rats. These wounds were named W1 (for inflammation analysis) and W2 (for collagen study).

\section{Treatment of wounds}

In group $A(n=30)$, immediately after the surgical procedure, the wounds were contaminated with the topical application (figure 2) of multibacterial standard solution $(0,1 \mathrm{ml}$ of $1 \mathrm{~g}$ of rats fresh feces and $1 \mathrm{ml}$ of saline). In the following day, the infected wounds of the subgroup A1 $(n=10)$ were topically treated with $1 \mathrm{ml}$ of saline solution. The sub-group A2 $(n=10)$ rats wounds were treated with an unique dosis of FGF- $\beta 10 \mathrm{ng}$ diluted in 10ìl of saline (Sigma, USA). In sub-group A3 $(n=10)$ rats, the wounds were topically treated with 10ng of FGF-ß + anti-FGF-ß (figure 3$)$. In group $B(n=30)$ rats, the wounds were not contaminated and the same topical treatments were accomplished as described to A.

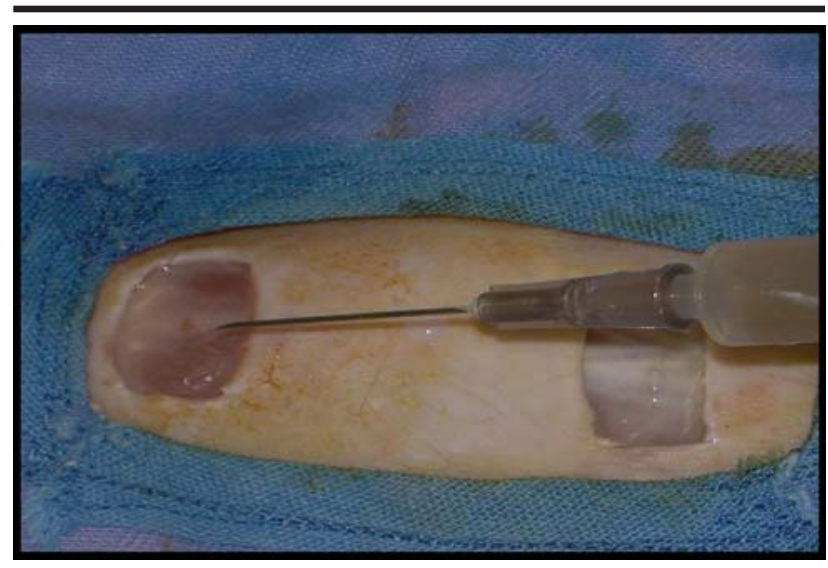

FIGURE 2 - Topical application of multibacterial solution on W1 and W2 wounds of group A.

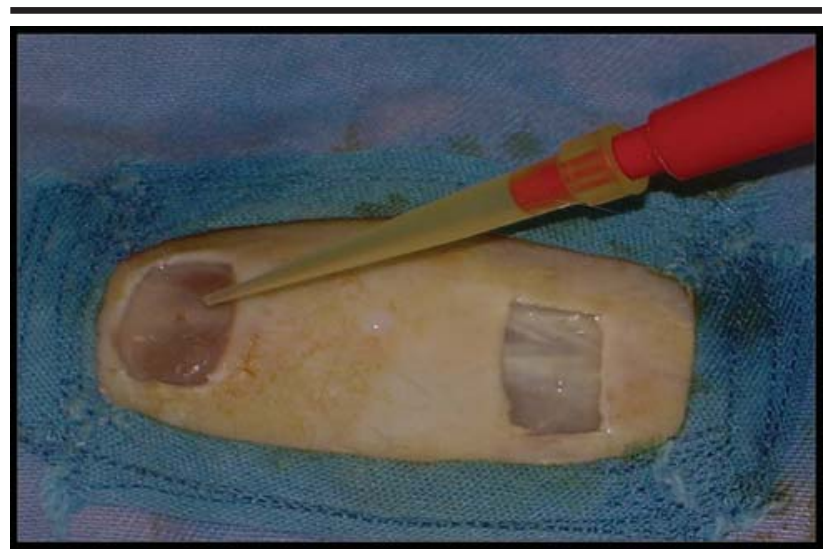

FIGURE 3 -Topical application of FGF $\beta$.

\section{Histological analysis}

In the eighth postoperative day the $\mathrm{W} 1$ wound was ressected and fixed in formaline $10 \%$ by 3 days. The biopsies were processed following the routine and stained with hematoxilin and eosin (HE) for histological analysis of the inflammatory reaction. The rats were observed until complete epithelialization of W2 wounds for determination of healing time. Under anesthesia, the wounds were ressected and prepared to measure the expression of types I and III collagen, using Picro Sirius Red (Direct Red 80 from Aldrich Chemical Co, USA) staining and polarized filters. The type I collagen was identified by its thick fibers and compact and dense fibrils, yellow to light red colored. The type III collagen formed green fine fibers with thin fibrils ${ }^{24}$. The variables were analysed by the optical microscope Olympus B-50 and the quantification of cells, fibers and elements of the inflammatory reaction was performed by the Image Pro-Plus Média Cybernetics software, LP, USA. The statistical analysis was performed by ANOVA, $t$ and Tukey tests, considering $\mathrm{p}<0.05$ as significant.

\section{Results}

\section{Time for healing}

The healing time of W2 infected wounds of subgroup A1 was 21,5 days; in the subgroup A2, 12,87days, and 20,87 days in the subgroup A3. In the non-infected wounds of subgroup B1 the healing time was 9,70 days, in the subgroup B2 13,50 days, and in the subgroup B3 15,40 days (Table 1). In infected wounds no treated with FGFb (subgroup A1) the healing time was comparable to the A3 rats, whose infected wounds were treated with FGFb and anti-FGFb $(p>0.05)$. When the infected wounds were treated with FGFb (subgroup A2) we observed a significant reduction in the healing time, when compared with A1 subgroup ( $\mathrm{p}<0.05)$. The same phenomenon was observed comparing the subgroups B1 and B2, meaning that FGFb remarkably contributed to accelerate the healing. The association of anti-FGFb in infected and no infected wounds, inhibited the beneficial effect of FGFb, as can be observed comparing subgroups A2-A3 and B2-B3 (Table 1).

\section{Histology}

The density of inflammatory cells in the subgroup A3, whose infected wounds were treated with FGFb and antiFGFb, was shorter than that observed in all the other subgroups. The difference was significant when compared the subgroup A3 to A2 and B2 $(\mathrm{p}<0.05)$. In the wounds treated with $\mathrm{FCFb}$, with and without infection (subgroups A2, B2), the density of fibroblasts contributed to a great density of inflammatory cells. (Table 2). The figures 4, 5 and 6 show histopathological details observed in the laminas of their respective subgroups. 
Qualitative and e quantitative analysis of type I colllagen

The density of type I collagen of subgroup B2 rats (treated with FGFb) was significantly higher $(\mathrm{p}<0.05)$ than in subgroup B1, using multiple comparisons by the Tukey test (Table 2). The figure 7 displays high density of collagen type I in histological preparation of no infected wound of subgroup B2, that can be compared with the low density observed in the figure 8 (subgroup A1). When the antiFGFb was used in the wounds (subgroups A3, B3), the density of the type I collagen had a significant reduction. In the infected wounds, the treatment with FGFb (subgroup A2) contributed to increase the density of the type I collagen, comparing to the control (subgroup A1). However, the differences in the density among those subgroups were not significant $(\mathrm{p}>0,05)$.

TABLE 1 - Expresses the mean of the healing time of the W2 wounds in each subgroup.

\begin{tabular}{c|r|c}
\hline Subgroups & Subgroups Treatment & Healing time (days)* \\
\hline A1 & Infection, no FGF $\beta$ & $21,50 \pm 1,60^{\mathrm{a}}$ \\
A2 & Infection + FGF $\beta$ & $12,87 \pm 0,83^{\mathrm{b}}$ \\
A3 & Infection + FGF ${ }^{2}+$ Anti- FGF $\beta$ & $20,87 \pm 1,64^{\mathrm{a}}$ \\
B1 & No infection, no FGF $\beta$ & $13,50 \pm 1,18^{\mathrm{c}}$ \\
B2 & No infection + FGF $\beta$ & $9,70 \pm 1,70^{\mathrm{b}}$ \\
B3 & No Infection + FGF $^{2}+$ Anti- FGF $\beta$ & $15,40 \pm 1,50^{\mathrm{d}}$ \\
\hline
\end{tabular}

* Mean \pm standard deviation.

Values identified with the same letter do not differ $(\mathrm{p}>0,05)$.

TABLE 2 - Mean of inflammatory cells and density of types I and III collagen. Histological analysis stained by HE and picro-sirius red, respectively.

\begin{tabular}{|c|c|c|c|c|}
\hline \multicolumn{2}{|c|}{ Groups and treatment } & \multirow{2}{*}{$\begin{array}{c}\text { INFLAMMATION HE*1 } \\
\text { 398,00 } \pm 211,51\end{array}$} & \multirow{2}{*}{$\frac{\text { COLLAGEN III }^{2}}{153,64 \pm 7,52^{* *}}$} & \multirow{2}{*}{$\frac{\text { COLLAGEN I }^{* 2}}{186,97 \pm 12,71^{* *}}$} \\
\hline A 1 & Infection, no FCF $\beta$ & & & \\
\hline A 2 & Infection + FCF $\beta$ & $519,87 \pm 122,37$ & $161,62 \pm 8,63^{a * *}$ & $193,28 \pm 7,29 * *$ \\
\hline A3 & Infecção + FCF $\beta$ + Anti-FCF $\beta$ & $307,37 \pm 102,22^{b}$ & $139,14 \pm 22,32^{a * *}$ & $178,69 \pm 29,89 * *$ \\
\hline B1 & No infection, no FCF $\beta$ & $354,60 \pm 120,08^{a}$ & $143,68 \pm 9,03^{* *}$ & $169,96 \pm 12,23^{\mathrm{a} * *}$ \\
\hline B2 & No infection + FCF $\beta$ & $603,62 \pm 213,17^{\mathrm{ab}}$ & $161,29 \pm 7,75^{* *}$ & $202,77 \pm 18,77^{a * *}$ \\
\hline B3 & No infection + FCF $\beta+$ Anti-FCF $\beta$ & $497,50 \pm 100,64$ & $65,38 \pm 14,92^{\S * *}$ & $174,25 \pm 19,04^{* *}$ \\
\hline
\end{tabular}

Mean \pm standard deviation

*Values identified with the same letter differ significantly. Tukey test, significance 0.05 .

**Significant difference comparing types I and III collagen ( $t$ test for pared data).

$\S$ Differ significantly comparing with of subgroups (Tukey test, $\mathrm{p}<0.05$ ).

1 - Number of inflammatory cells.

2 - Color density (green - red).

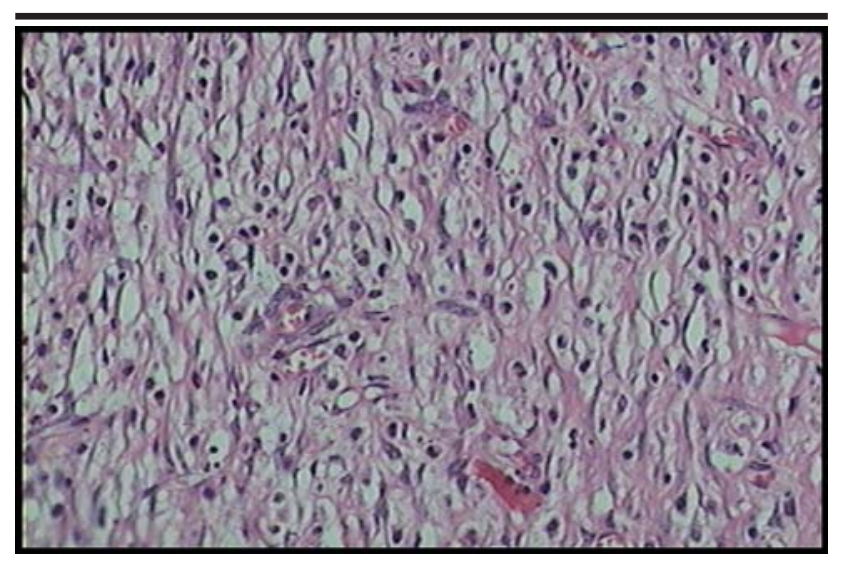

FIGURA 4 - Photomicrography of no infected wound treated with FGF $\beta$ (subgroup B2), showing intense inflammatory reaction. H-E, 100x).

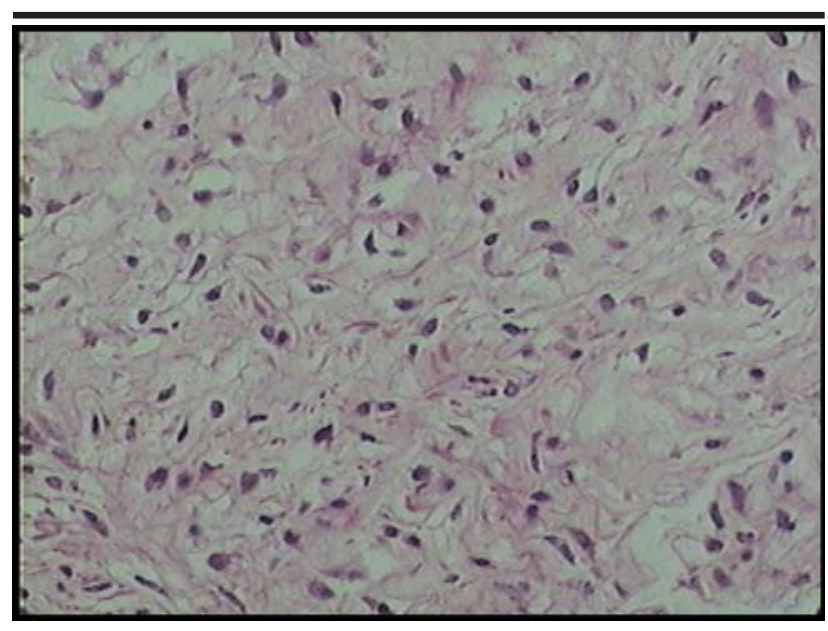

FIGURA 5 - Photomicrography indicating low inflammatory reaction in no infected wound of subgroup B1 rat. H-E, 100x. 


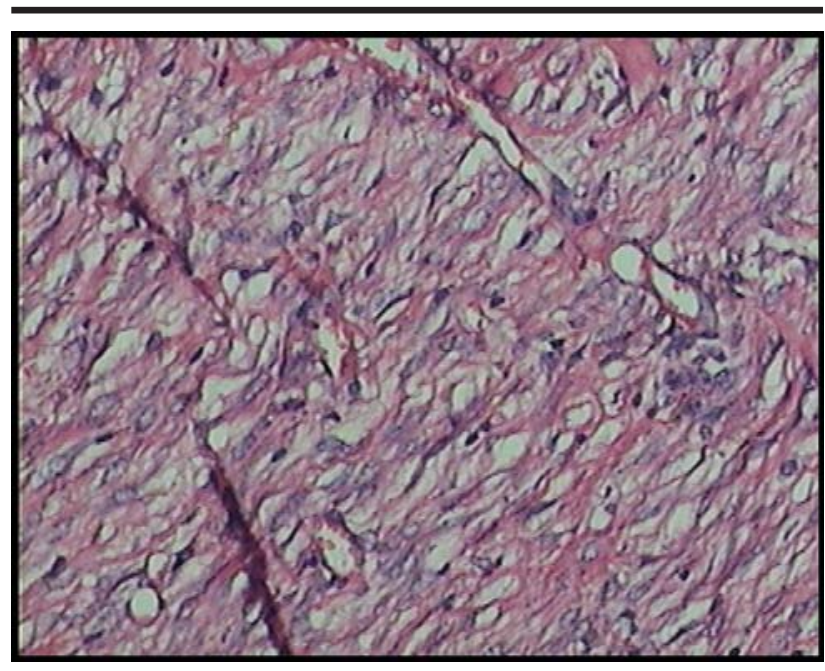

FIGURE 6 - Photomicrography of infected wound treated with FCF $\beta$ +anti-FCF $\beta$ (subgroupA3). H-E, 100x.

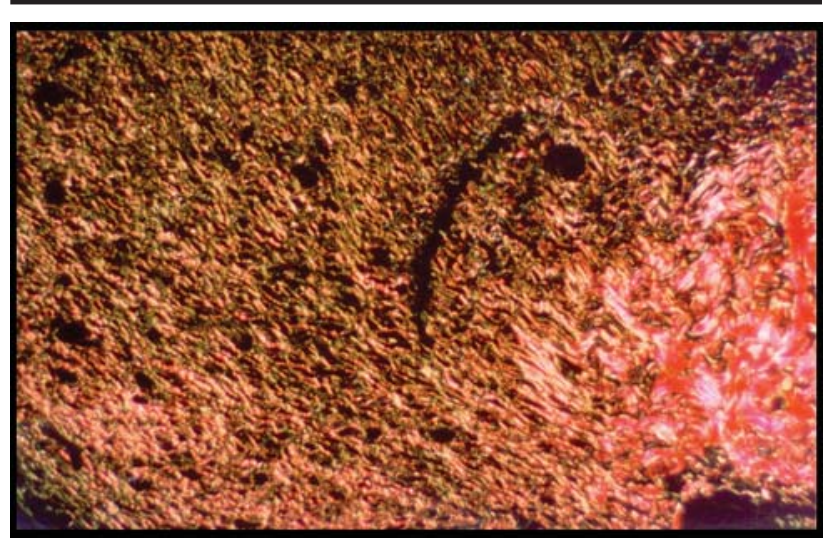

FIGURE 7 - Photomicrography of infected wound of subgroup B2, treated with FCF $\beta$. A high density of type I collagen (red color) is observed. (picro-sirius red, 200X).

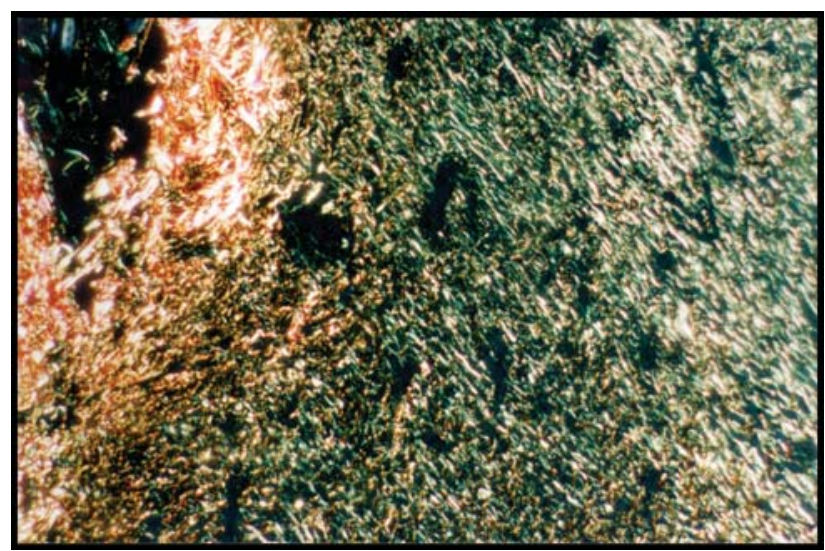

FIGURE 8 - Photomicrography of no infected wound of subgroup A1, showing low density of type I collagen. (picro-sirius red, 200x).

\section{Analysis of type III collagen}

Analyzing the expression of the type III collagen, it was observed that FGFb didn't stimulate its production in infected and no infected wounds, when compared with the controls $(p>0.05)$. The treatment of wounds with anti-FCFß reduced significantly the density of type III collagen when those subgroups were compared with the wounds (A2, B2) treated with FCFß $(\mathrm{p}<0.05)$. The expression of the collagen type I was always significantly greater than the observed in type III collagen of all the other subgroups (Table 2). The figure 9 demonstrates the low density of type III collagen in infected wound of the subgroup B3, where rare green fibers are seen. In figures 10 (subgroup A1), 11 (of the subgroup A3) and 12 (subgroup B2), a high density of the type III collagen is observed.

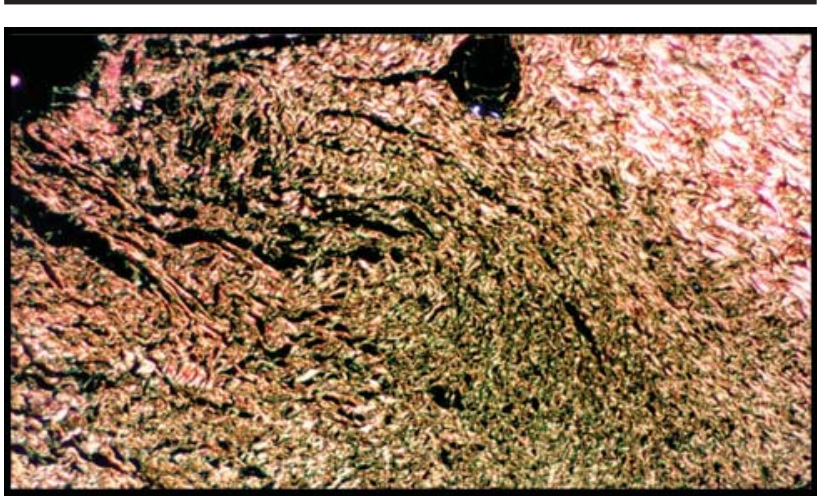

FIGURE 9 - Photomicrography of no infected wound of subgrupo B3 rat. Low density of type III collagen (green collor). Picro-sirius red, 200x.

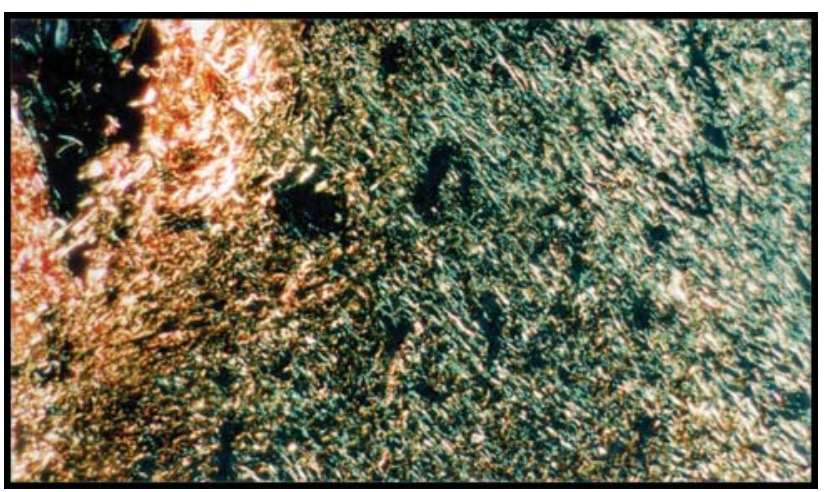

FIGURE 10 - High density of type III collagen (green) in no infected wound of subgroup A1 rat. Picrosirius red, 200x. 


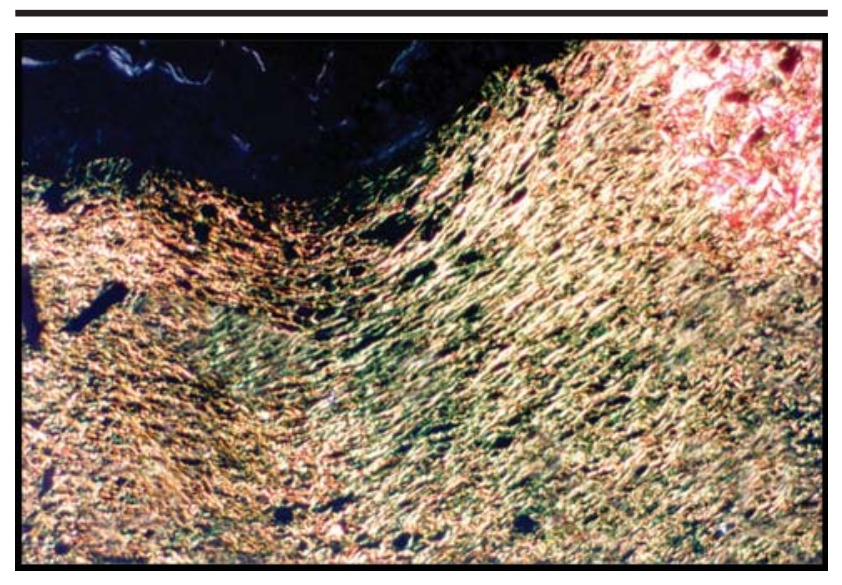

FIGURE 11 - Photomicrography of infected wound treated with FCF $\beta$ +anti-FCF $\beta$, subgroup A3. A high density of type III collagen is shown. (picrosirius red, 200x).

\section{Discussion}

Injury to the skin initiates a cascade of events including inflammation, new tissue formation, and tissue remodeling, which finally lead to reconstruction of the wounded area ${ }^{16,17}$. The repair process is initiated immediately after injury by the release of various growth factors, cytokines, and low-molecular weight compounds from the serum of injured blood vessels and from degranulating platelets. Disruption of blood vessels also leads to the formation of the blood clot, which is composed of cross-linked fibrin, and of extracellular matrix proteins such as fibronectin, tenascin, and thrombospondin ${ }^{16,17,18}$. The healing is an important phenomenon of the surgical treatment, and involves resistance of the sutured tissues, esthetics and recovery of function. In the management of skin wounds these aspects are essencial ${ }^{1,2,3,4}$. The experimental surgical model used in this work allowed the analysis of the effects of FGFb on inflammation and on expression of types I and III collagen using the histochemical method with picrosirius red staining, exposed to polarized light ${ }^{25,26}$. Multiple studies have demonstrated a beneficial effect of many growth factors, e.g., platelet-derived growth factors (PDGFs), fibroblast growth factors (FGFs), and granulocyte-macrophage colony stimulating factor (GMCSF) on the healing process, both in animal models and also in patients suffering from different types of wound healing disorders and infection ${ }^{27,28,29,30,31}$. Using an only dosis of $10 \mu \mathrm{g} / \mathrm{ml}$, they observed a reduction in the healing time. In the same way, Hayward et al revealed that chronic burns benefit with the topical application of FGFb $(100 \mu \mathrm{g} /$ $\mathrm{ml})^{7}$. The results of the present work revealed that the infection affects the healing time delaying the scaring of the open wounds, as seen in infected ones with no topical treatment with FGFb, where the mean healing time was of 21,5 days. When the infected wounds were topically treated with FGFb, the mean healing time was 12,8 days.

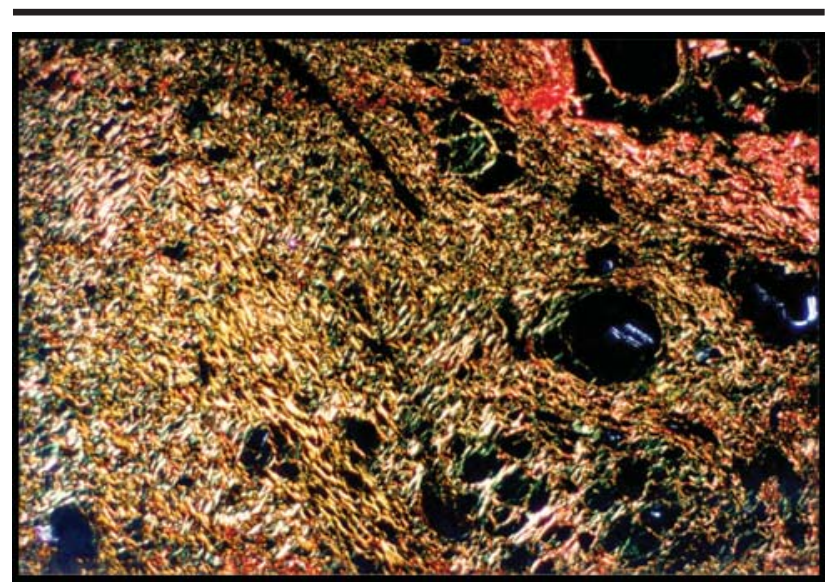

FIGURE 12 - Photomicrography of no infected wound treated with FCF $\beta$ (subgroup B2). A high density of type III collagen is shown (picrosirius red, 200x).

The exact biological mechanisms involving FGFs is controversial. The roles of endogenous growth factors in the healing response have been only partially elucidated. However, in vivo functions of many growth factors remain largely unconfirmed. The FGFs have a broad mitogenic spectrum. They stimulate proliferation of various cells of mesodermal, ectodermal, and also endodermal origin. In addition to their mitogenic effects, FGFs also regulate migration and differentiation of their target cells, and FGFs have been shown to be cytoprotective and to support cell survival under stress conditions $^{32,33}$. Numerous in vivo effects of FGFs have been demonstrated, which suggest a role of these growth factors in wound repair. In particular, FGFb was shown to stimulate angiogenesis in various assay systems ${ }^{34}$. Furthermore, FGFs are mitogenic for several cell types present at the wound site, including fibroblasts and keratinocytes $^{27}$. Thus FGFs are clear candidates for contributing to the wound healing response, and this hypothesis has been corroborated by a number of studies where their local application stimulated tissue repair ${ }^{35}$. Mcgee et al and Slavin et al observed acceleration of wound healing time in diabetic rats, in chorticosteroid use and in infected wounds with an isolated topical application of FGFß. They observed increase in angiogenesis, fibroblasts proliferation and great deposition of collagen, comparing with controls ${ }^{15,23}$. In clinical studies, it was made the topical use of FGFß in chronic peptic ulcers, in decubitus ulcers and in ocular lesions. The authors observed reduction in healing time and significant deposition of collagen in wounds ${ }^{21,24}$. Medeiros et al observed that the topical application of a single dose FGFß in sutured skin wounds of rats stimulated the lymphocytes and fibroblasts proliferation, increased the collagen synthesis and tensil strength of wounds ${ }^{14}$. However, Stenberg et al, using a similar experimental design of the present work, demonstrated that FGFß enhances infected wounds, but does not 
increase tensil strength ${ }^{10}$. The collagen fibers are important components of the extracelular matrix, responsible for the tensil resistance of the wounds ${ }^{3,5,12}$. The role of FGF in wound repair was finally clarified when FGF null mice were used for wound healing studies. When they were challenged by full-thickness excisional wounding, they showed delayed healing ${ }^{35}$. In addition to a retardation in the rate of reepithelialization, mice null for FGF2 showed reduced collagen deposition at the wound site, and they had thicker scabs ${ }^{35}$. The tensil strength of operative wounds depends on some factors, such as the collagen level and the thickness and organization of their fibers ${ }^{1}$. It was demonstrated in the present work that the topical application of FGFß stimulated the deposition of types I and III collagen as observed in other studies ${ }^{14,15}$. The concomitant use of FGFß and anti-FGFß antibody in open infected and clean wounds inhibited the collagen synthesis. To provide functional evidence for a role of FGF in wound repair, Broadley et $\mathrm{al}^{11}$ used a neutralizing polyclonal antibody that was raised against human FGF. They incorporated the purified IgG into sponge disk, and the disks were then implanted subcutaneously under ventral panniculus carnosus of rats. The continuous release of the antibody caused a striking reduction in cellularity and vascularization compared with the granulation tissue formed in the control IgG sponges. In addition, DNA, protein, and collagen levels in the anti-FGF sponges were reduced by $25-35 \%$ relative to control at day 7 after implantation. This study strongly suggested an important role of endogenous FGF in wound repair. The application of FCFß increased the global synthesis of the collagen, in higher intensity the type I than type III collagen. This finding must have contributed strongly to the maturation of collagen corroborated by several studies $2,3,4,7,12,14,15,36,37,38,39,40,41$.

\section{Conclusion}

The topical treatment with FCFb influenced the evolution of infected and clean skin wounds of rats. The healing time was accelerated, the inflammatory reaction was favorable as well as the deposition of I and III collagen. The antibody anti-FCFb neutralized the FCFb effects.

\section{References}

1. Herndon D, Hayward P, Ratan R, Barrow R. Growth hormones and factors in surgical patients. Adv Surgery. 1992; 25: 65-97.

2. Cromack D, Porras-Reyes B, Mustoe T. Currents concepts in wound healing: growth factor and macrophage interaction. J Trauma. 1990;30:129-33.

3. Abercombie M Flint MH, James DW. Wound contraction in relation to collagen formation in scorbutic guinea pigs. J Embriol Expl Morph. 1956; 4: 167-73.
4. Mcgrath MH, Simon RH. Wound geometry and kinetics of wound contraction. Plast Reconstr Surg. 1983;1:66-72.

5. Ehrlick HP, Grislis G, Hunt TK. Evidence for the envolviment of microtubules in wound contraction. Am J Surg 1977;133: 703-6.

6. Skalli O, Gabbiani G. The biology ofthe myofibroblast relationship to wound contraction and fibrocontractive diseases. In; R A F Clark, PM Henson. The molecular and cellular biology of wound repair 1988; New York: Plenum, chap. 17, 373-402.

7. Hayward P, Hokanson J, Heggrs J. Fibroblast growth factor reserves the bacterial retardation of wound contraction. Am J Surg. 1992; 163:288-93.

8. Perry AW, Sutkin HS, Gottlieb LD. Skin graft survivalThe bacterial answear. Ann Plast Surg. 1989; 22:47983.

9. Peacock JR E E. A cicatrização e os cuidados com as feridas. In: Schwartz, Seymour I, Shires G, T, Frank S C. Princípios de Cirurgia. 5.ed. Rio de Janeiro: Editora Guanabara Koogan,_1991.Cap. 8, p. 251-271.

10. Stenberg BD, Phillips LG, Hokanson JA. Effect of bfgf on the inhibition of contraction caused by bacteria. J Surg Res. 1999; 50: 47-50.

11. Broadley KN, Aquino AM, Woodward SC, BuckleySturrock A, Sato Y, Rifkin DB, Davidson JM. Monospecific antibodies implicate basic fibroblast growth factor in normal wound repair. Lab Invest. 1989; 61: 571-5.

12. Ono I, Tateshita T, Inoue $M$. The collagen matrix containing basic fibroblast growth factor on wound contraction. J Biomed Master Res. 1999; 48:251-71.

13. Kamamoto F, Paggiaro AO, Rodas A. A wound contraction experimental model for studing keloides and wound healing modulators. Artif Org. 2003; 27:701-5.

14. Medeiros AC, Dantas Filho AM, FP Lima et al. Efeitos do fator de crescimento de fibroblastos na cicatrização da pele de ratos. Anais Fac Med Univ Fed Pernambuco. 2001; 46:78-82.

15. McGee G, Davdson J, Bukley A. Recombinant basic fibroblast growth factor accelerates wound healing. J Surg Res. 1988; 45:145-53.

16. Clark RAF. Wound repair. Overview and general considerations. In: The Molecular and Cellular Biology of Wound Repair (2nd ed.), edited by Clark RAF. New York: Plenum, 1996, p. 3-50.

17. Martin P. Wound healing - aiming for perfect skin regeneration. Science 276: 75-81, 1997

18. Clark RAF. Regulation of fibroplasia in cutaneous wound repair. Am J Med Sci. 1993; 306: 42-8.

19. Fiddes J, Hebda P, Hayward P. Preclinical woundhealing studies with recombinant human basic 
fibroblast growth factor. Ann N Y Acad Sci._1991; 638: 316-28.

20. Yayon A, Klagsbrum M. Autocrine regulation of cell growth and transformation by basic fibroblast growth factor. Cancer Metast Rev. 1990; 9:191-202.

21. Folkman J, Klagsbrum M. Angiogenic factors. Science. 1987; 235: 442-447.

22. Davidson J, Broadley K. Manipulation of the wound healing process with basic fibroblast growth factor. Ann NY Acad Sci. 1991; 638: 306-15.

23. Slavin J, Nash J, Kingsnorth A. Effect of transforming growth factor beta and basic fibroblast growth factor on steroid-impaired healing intestinal wounds. Br J Surg. 1992; 79: 69-72.

24. Robson M, Phillips L, Lawrence W. The safety and effect of topically applied recombinant basic fibroblast growth factor on the healing of cronic pressure sores. Ann Surg. 1992; 216: 401-8.

25. Cuttle L, Nataatnadja M, Fraser JF. Collagen in the scarless fetal skin wound: detection with picrosirius red. Wound Rep Reg. 2005; 13: 198-204.

26. Junqueira LCU, Cossermely W, Brentani R. Diferential staining of collagens type-I, Type-II and Type-III by picrosirius red and polarization microscopy. Arch Hist Japn. 1978; 41: 267-74.

27. Abraham JA, Klagsbrun M. Modulation of wound repair by members of the fibroblast growth factor family. In: The molecular and cellular biology of wound repair (2nd ed.), edited by Clark RAF. New York: Plenum, 1996, p. 195-248.

28. Edmonds M, Bates M, Doxford M, Gough A, Foster A. New treatments in ulcer healing and wound infection. Diabetes Metab Res Rev. 2000;16 Suppl 1: S51-S4.

29. Greenhalgh DG. The role of growth factors in wound healing. J Trauma. 1996;41:159-67.

30. Harding KG, Morris HL, Patel GK. Science, medicine and the future: healing chronic wounds. Br Med J.
2002;324:160-3.

31. Nath C, Gulati SC. Role of cytokines in healing chronic skin wounds. Acta Haematol. 1998;99:175-9.)

32. Basilico C, Moscatelli D. The FGF family of growth factors and oncogenes. Adv Cancer Res. 1992;.59: 115-65.

33. Werner S. Keratinocyte growth factor: a unique player in epithelial repair processes. Cytokine Growth Factor Rev.1998; 2: 153-65.

34. Risau W. Angiogenic growth factors. Prog Growth Factor Res.1990; 2:71-9.).

35. Ortega S, Ittmann M, Tsang SH, Ehrlich M, Basilico C. Neuronal defects and delayed wound healing in mice lacking fibroblast growth factor 2. Proc Natl Acad Sci USA. 1998;95: 5672-7.

36. Gosporadowicz D. Basic Science and pathology: Fibroblast growth factor: Chemical structure and biologic function. Clin Orthop Res. 1990; 257:231-48.

37. Greenhalgh DG, Sprugel KH. Murray MJ, Ross R. PDGF and FGF stimulate wound healing in the genetically diabetic mouse. Am J Pathol. 1990;136:1235-46.

38. Herba PA, Klingbeil CK, Abrahan JA. Basic fibroblast growth stimulation of epidermal wound healing in pigs. J Invest Dermathol. 1990; 95: 626-31.

39. Imaizumi T, Jean-Luis F, Dubertret ML. Effect of human basic fibroblast growth factor on fibroblast proliferation, cell volume, collagen latice contraction: in comparison with acid type. J Dermathol Sci. 1996; 11: 134-41.

40. Kanda T, Funato N, Baba Y. Evidence for fibroblast growth factor receptors in myofibroblasts during palatal mucoperiosteal repair. Arch Oral Biol. 2003;48:213-21.

41. Loumanen M, Lehto VP, Meurman JH. Myofibroblast in healing laser wounds of rat tongue mucosa. Arch. Oral Biol. 1988; 33:17-23.

\section{Correspondence:}

Aldo Cunha Medeiros

Av. Miguel Alcides Araújo, 1889

59078-270 Natal-RN Brazil
Conflict of interest: none

Financial source: none 